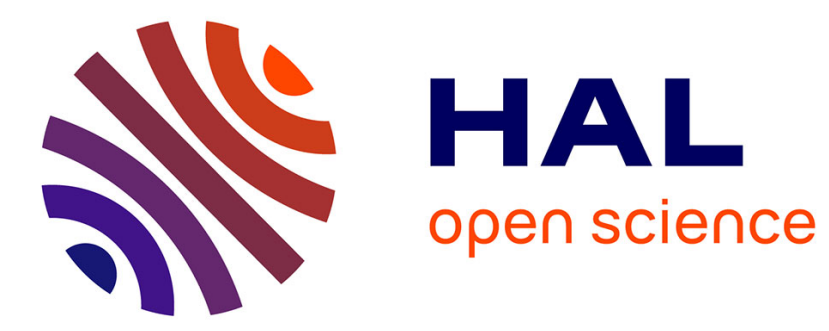

\title{
Sustainability indicators for livestock farming. A review
}

Thérésa Lebacq, Philippe Baret, Didier Stilmant

\section{To cite this version:}

Thérésa Lebacq, Philippe Baret, Didier Stilmant. Sustainability indicators for livestock farming. A review. Agronomy for Sustainable Development, 2013, 33 (2), pp.311-327. 10.1007/s13593-012-0121x . hal-01201364

\section{HAL Id: hal-01201364 \\ https://hal.science/hal-01201364}

Submitted on 17 Sep 2015

HAL is a multi-disciplinary open access archive for the deposit and dissemination of scientific research documents, whether they are published or not. The documents may come from teaching and research institutions in France or abroad, or from public or private research centers.
L'archive ouverte pluridisciplinaire HAL, est destinée au dépôt et à la diffusion de documents scientifiques de niveau recherche, publiés ou non, émanant des établissements d'enseignement et de recherche français ou étrangers, des laboratoires publics ou privés. 


\title{
Sustainability indicators for livestock farming. A review
}

\author{
Thérésa Lebacq · Philippe V. Baret • Didier Stilmant
}

Accepted: 23 October 2012 /Published online: 16 November 2012

(C) INRA and Springer-Verlag France 2012

\begin{abstract}
Intensive livestock farming has raised issues about environmental impacts and food security during the past 20 years. As a consequence, there is a strong social demand for sustainable livestock systems. Sustainable livestock systems should indeed be environmentally friendly, economically viable for farmers, and socially acceptable, notably for animal welfare. For that goal, many sustainability indicators and methods have been developed at the farm level. The main challenge is using a transparent selection process to avoid assessment subjectivity. Here, we review typologies of sustainability indicators. We set guidelines for selecting indicators in a data-driven context, by reviewing selection criteria and discussing methodological issues. A case study is presented. The selected set of indicators mainly includes (1) environmental indicators focusing on farmer practices; (2) quantitative economic indicators; and (3) quantitative social indicators with a low degree of aggregation. The selection of indicators should consider (1) contextualization to determine purpose, scales, and stakeholders involved in the assessment; (2) the comparison of indicators based on various criteria, mainly data availability; and (3) the selection of a minimal, consistent, and sufficient set of indicators. Finally, we discuss the following issues: topics for which no indicators are measurable from available data should explicitly be mentioned in
\end{abstract}

T. Lebacq $(\bowtie) \cdot$ P. V. Baret

Earth and Life Institute-Agronomy,

Université catholique de Louvain (UCL),

Croix du Sud 2, L7.05.14,

1348 Louvain-la-Neuve, Belgium

e-mail: theresa.lebacq@uclouvain.be

T. Lebacq $\cdot$ D. Stilmant

Unité Systèmes agraires,

Territoire et Technologies de l'information, Centre wallon de

Recherches agronomiques (CRA-W),

Rue de Serpont 100,

6800 Libramont, Belgium the results. A combination of means-based indicators could be used to assess a theme, but redundancy must be avoided. The unit used to express indicators influences the results and has therefore to be taken into account during interpretation. To compare farms from indicators, the influence of the structure on indicator values has to be carefully studied.

Keywords Sustainability assessment - Indicator selection . Data-driven approach $\cdot$ Livestock farming systems

\section{Contents}

1. Introduction. . . . . . . . . . . . . . . .

2. Overview and characterization of sustainability indicators. . . . . . . . . . . . . .

2.1. Environmental sustainability . . . . . . . 3

2.2. Economic sustainability . . . . . . . . 4

2.3. Social sustainability ............. 5

3. Selection of sustainability indicators . . . . . . . 6 6

3.1. Contextualization . . . . . . . . . . 7

3.2. Comparison and evaluation of indicators. . .9

3.2.1. Relevance . . . . . . . . . 9

3.2.2. Practicability ............ 10

3.2.3. End user value . . . . . . . . . 10

3.3. Selection of a set of indicators ........11

4. Key issues involved in the assessment . . . . . . 12

4.1. Gaps in the sustainability assessment . . . .12

4.2. Use of means-based indicators . . . . . . . .12

4.3. Choice of functional units . . . . . . . . . 13

4.4. Use of indicators to compare systems . . . . 13

5. Selection of indicators to analyze the sustainability of Walloon dairy and beef livestock systems . . . . . . 13

5.1. Contextualization . . . . . . . . . . . . 13

5.2. Selection process . . . . . . . . . . . . . 14

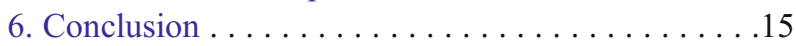

7. Acknowledgments . . . . . . . . . . . . 16

8. References. .....................16 


\section{Introduction}

During the twentieth century, developments in agriculture led to intensification and specialization of livestock production systems. The long-term viability of these systems is now questioned, however, due to crises related to animal diseases and detrimental effects on farm income, animal welfare, and the environment (Rigby et al. 2001; ten Napel et al. 2011; van Calker 2005). There are less social acceptance of such intensive and specialized systems and demand for more sustainable livestock farming systems, i.e., that are economically viable for farmers, environmentally friendly, and socially acceptable (Boogaard et al. 2011; ten Napel et al. 2011) (Fig. 1).

Sustainability assessment is a key step in supporting the development of sustainable farming systems (Sadok et al. 2008). In practice, it involves dividing the aforementioned three dimensions of sustainability into various issues of concern (Gómez-Limón and Sanchez-Fernandez 2010), called objectives, attributes, or themes (Alkan Olsson et al. 2009; Binder et al. 2010; van Calker 2005; van der Werf and Petit 2002), and assessing these objectives using indicators (van der Werf and Petit 2002). An indicator is defined as " $a$ variable which supplies information on other variables which are difficult to access and can be used as a benchmark to make a decision" (Gras 1989). Over the past few decades, there has been an "indicator explosion" (Riley 2001a), with the development of indicator-based assessment methods, at regional, farm, or cropping system levels. This multiplicity of indicators and assessment tools raises questions and is a source of confusion for potential users (Bockstaller et al. 2009). The key question in this field has therefore shifted from "how do we develop an indicator?" to

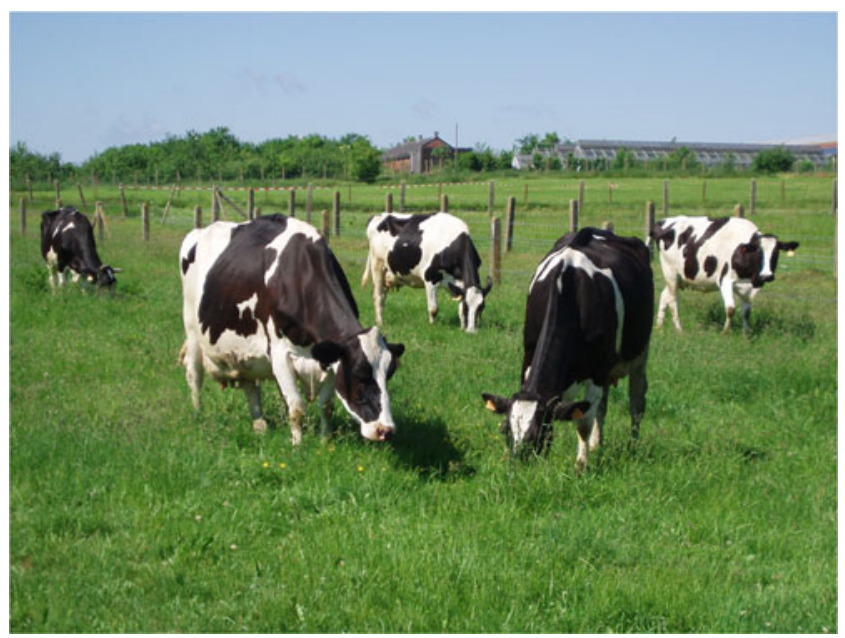

Fig. 1 Intensive livestock farming systems have several potential environmental impacts, such as eutrophication, groundwater pollution by nitrates, and greenhouse gas emissions "which indicators can we use?," highlighting the issue of indicator selection (Bockstaller et al. 2008).

We identified three approaches in terms of sustainability assessment: (1) the method-based approach in which an existing assessment method is selected to perform an evaluation; (2) the objective-driven approach, which aims to develop an assessment method by selecting indicators and collecting the necessary data; and (3) the data-driven approach, which consists of selecting and calculating indicators from existing data. Data-driven approaches, such as assessments based on farm accounting data, have several fields of application: (1) analysis of diversity within a representative set of farms; (2) analysis of changes over a period of time; and (3) definition of regional targets in certain sustainability themes (Meul et al. 2007).

With a method-based approach, the challenge is to select a suitable method, which is why several authors have compared indicators-based methods to suggest selection guidelines (Bockstaller et al. 2009; Galan et al. 2007; Halberg et al. 2005a; Payraudeau and van der Werf 2005; van der Werf and Petit 2002; van der Werf et al. 2007). With objectivedriven and data-driven approaches, the challenge is to select an appropriate set of indicators. To address this issue, various works describe and characterize indicator diversity: typologies of agrienvironmental indicators (Bockstaller et al. 2008; Payraudeau and van der Werf 2005; van der Werf and Petit 2002; van der Werf et al. 2009), comparisons, evaluations (Aveline et al. 2009; Thomassen and de Boer 2005), and inventories of indicators. These inventories have been performed for specific environmental topics, such as pesticide risks (Devillers et al. 2005), and nitrogen management (CORPEN 2006), or for specific purposes, such as the French territorial observatory of agricultural practices (Guillaumin et al. 2007), or the design of a tool to assess and compare the sustainability of options of the Common Agricultural Policy (Geniaux et al. 2006).

However, few works specifically deal with indicator selection in the data-driven approach. In this perspective, Halberg et al. (2005a) highlighted the need for consensus on a list of environmental indicators to assess livestock farming systems and proposed a structure for indicator selection, based on geographical scale, system boundary, and the purpose of the assessment. On the other hand, most of the studies focus on environmental impacts of agricultural systems, without taking into account economic and social components (Darnhofer et al. 2010), leading to an imbalance between the three dimensions of sustainability. In this context, the main objective of this review is to analyze how to select a set of environmental, economic, and social indicators in order to assess the sustainability of livestock farming systems. Our paper focuses on data-driven assessments performed at farm level, from available databases, and without additional data collection. Due to the diversity of 
assessments in terms of objectives, end users, and available data, our objective is not to provide a predefined set of indicators. This article is in two parts: (1) an initial general section describing typologies of sustainability indicators in order to understand their diversity and structure and (2) two practical sections aiming to help users to select a set of indicators by summarizing the selection criteria used in sustainability assessments and highlighting some key methodological issues to be taken into account in the selection process. The issues reviewed here are illustrated by means of a case study on the analysis of sustainability of Walloon livestock systems, from farm accounting databases.

\section{Overview and characterization of sustainability indicators}

\subsection{Environmental sustainability}

Numerous examples exist in the literature concerning the use of agro-ecological indicators to assess environmental impacts of farming systems (Bechini and Castoldi 2009; Bockstaller et al. 2008). To structure these indicators, several typologies have been presented in the literature (Bockstaller et al. 2008; Payraudeau and van der Werf 2005; van der Werf and Petit 2002; van der Werf et al. 2009). These are based on the causal chain between agricultural practices and their impacts, and underline the indirect link between practices and impacts due to the influence of external factors, such as soil characteristics or weather (van der Werf et al. 2009). These typologies differ according to the description of each level of the causal chain. Based on these analyses, we use a typology defining four kinds of indicators: (1) means-based indicators assessing technical means and inputs used on the farm, e.g., the livestock stocking rate; (2) system-state indicators concerning the state of the farming system, e.g., amount of post-harvest soil nitrate; (3) emission indicators related to the farm's polluting emissions into the environment and the potential impact of these emissions, e.g., estimated amount of nitrates lost to groundwater and surface water; and (4) effectbased indicators reflecting the impact of the practices on the environment and consisting of direct measurements, e.g., actual nitrate concentration in groundwater.

There is a duality between means-based and effect-based indicators in terms of measurability and environmental relevance. Measurability is related to the question "is the indicator easy to implement?," while environmental relevance answers the question "does the indicator reflect environmental impacts?" On the one hand, means-based indicators are easy to implement with regard to data availability and calculation but have a low quality of prediction of environmental impacts (van der Werf and Petit 2002; van der Werf et al. 2009). On the other hand, effect-based indicators have a high environmental relevance, due to their direct link with the objectives and their context specificity, but are difficult to implement from a methodological or practical point of view. Moreover, data collection is often more expensive (Chardon 2008; van der Werf and Petit 2002). Assessment tools using such indicators are consequently more difficult to implement because they are more complex, time-consuming, or require not directly available data (van der Werf et al. 2009). Effect-based indicators also usually cover a larger spatial scale than the farm, such as regional or watershed scale. With respect to the use of indicators on-farm, means-based indicators are more suitable because they are easy to implement and sensitive to production practices. In contrast, effect-based indicators do not enable cause-effect relationships to be monitored, making it difficult to use them to formulate specific advice for farmers (Bockstaller et al. 2008). However, some authors underline that the choice of means to reduce environmental impact is then left to the farmers themselves (Chardon 2008; van der Werf and Petit 2002). For instance, the farmer can choose the measures to implement in order to decrease nitrate concentration in groundwater.

System-state and emission indicators constitute an intermediate category. Both are linked, and system-state indicators could be included in emission indicators since they are variables that serve as inputs into the latter. Three types of emission indicators, with different levels of complexity, can be identified. Firstly, nutrient balances are calculated as the difference between inputs entering and outputs leaving the system. The surplus is then assumed to be lost to the environment (Thomassen and de Boer 2005). However, even if this indicator is useful in improving farmers' practices, it is considered to have a low quality of prediction for nitrogen losses (Chardon 2008). Secondly, some indicators derived from life cycle analysis (LCA), such as the global warming potential, use emission factors to evaluate the potential impacts of agricultural activities. These indicators consider system boundaries extending from production of inputs to the farm exit, i.e., "cradle-to-farm-gate" (Thomassen and de Boer 2005). Thirdly, some indicators are calculated from mechanistic model outputs. These model-based indicators link farmers' practices with environmental issues more directly, but their complexity is the main limitation for their use (Bockstaller et al. 2008; Halberg et al. 2005b). They can also include factors that are not controlled by the farmer, such as climate or soil type (Halberg et al. 2005b). Table 1 summarizes this typology and the characteristics of the indicators, related to the calculation method, data availability, and environmental relevance.

Various classifications of environmental indicators and objectives exist in the literature (Alkan Olsson et al. 2009; Meul et al. 2008; Sadok et al. 2009; van der Werf and Petit 2002). Such a classification is a challenge since some indicators can be sorted in various ways. For example, pesticide 
Table 1 Description of the typology of environmental indicators and characterization of these types, in terms of calculation method, data availability, and environmental relevance, in the context of a data-driven approach

\begin{tabular}{|c|c|c|c|c|c|c|c|}
\hline Type & & Example & Definition & Calculation & $\begin{array}{l}\text { Spatial } \\
\text { scale }\end{array}$ & $\begin{array}{l}\text { Data } \\
\text { availability }\end{array}$ & $\begin{array}{l}\text { Environmental } \\
\text { relevance }\end{array}$ \\
\hline \multicolumn{2}{|l|}{ Means-based indicators } & Livestock stocking rate & Agricultural practices & Single variables & $\mathrm{P} / \mathrm{F}$ & ++ & - \\
\hline \multirow[t]{5}{*}{$\begin{array}{l}\text { Intermediate } \\
\text { indicators }\end{array}$} & System-state & $\begin{array}{l}\text { Amount of post-harvest } \\
\text { soil nitrate }\end{array}$ & $\begin{array}{l}\text { State of the farming } \\
\text { system }\end{array}$ & $\begin{array}{l}\text { Single variables, } \\
\text { direct } \\
\text { measurements }\end{array}$ & $\mathrm{P} / \mathrm{F}$ & $+/-$ & $+/-$ \\
\hline & Emissions & & \multirow{4}{*}{$\begin{array}{l}\text { Emissions of } \\
\text { greenhouse } \\
\text { and acidifying gases, } \\
\text { nutrients, pesticides } \\
\text { into the environment } \\
\text { and potential impacts }\end{array}$} & & & & \\
\hline & $\begin{array}{c}\text { Nutrient } \\
\text { balance }\end{array}$ & $\begin{array}{l}\text { Farm-gate nitrogen } \\
\text { surplus }\end{array}$ & & $\begin{array}{l}\text { Combination of } \\
\text { variables }\end{array}$ & $\mathrm{F}$ & + & $+/-$ \\
\hline & LCA & $\begin{array}{l}\text { Eutrophication } \\
\text { potential }\end{array}$ & & Emission factors & $\mathrm{F}+$ & $+/-$ & + \\
\hline & Model-based & $\begin{array}{l}\text { Nitrogen leaching } \\
\text { modeling }\end{array}$ & & Modeling & $\mathrm{P} / \mathrm{F} / \mathrm{R}$ & - & + \\
\hline \multicolumn{2}{|l|}{ Effect-based indicators } & $\begin{array}{l}\text { Nitrate concentration } \\
\text { in groundwater }\end{array}$ & Environmental impact & Direct measurements & $\mathrm{W} / \mathrm{R}$ & -- & ++ \\
\hline
\end{tabular}

There is a duality between means-based indicators that are easy to implement but have a low quality of prediction of environmental impacts, and effect-based indicators that directly reflect environmental impacts but are difficult to implement. System-state and emission indicators, ranging from balances to complex model-based indicators, have an intermediate position. Sources: Bockstaller et al. 2008; van der Werf and Petit 2002; van der Werf et al. 2009

$L C A$ life cycle analysis; $P$ parcel level; $F$ farm level; $F+$ farm level, including upstream activities (e.g., production and transport of inputs); $R$ regional level; $W$ watershed level;,,$++++/-,-,--$ relative degree of data availability and environmental relevance

use has an impact on different environmental compartments: air, water and soil quality, and on biodiversity. We decided to group environmental indicators found in the literature into ten environmental themes related to nutrients, pesticides, non-renewable resources (i.e., energy and water), land management, emissions of greenhouse gases and acidifying substances, biodiversity, and physical, chemical, and biological soil quality. The four first relate to input management, while the others concern the quality of natural resources (Fig. 2). Water quality is not mentioned separately here since indicators for this aspect mainly concern nutrients and pesticides. Our list of indicators and themes is not exhaustive and could constantly be supplemented, based on a wealth of literature about sustainability assessments. For an overview of environmental themes, please refer, for instance, to Alkan Olsson et al. (2009) and van der Werf et al. (2007).

Figure 2 shows the division of sustainability into dimensions and themes. This classification has the drawback of not clearly representing trade-offs between and within dimensions, for example between nutrient management and greenhouse gas emissions. Within each of these themes, indicators have been classified according to the typology described above. Figures 3 and 4 give an overview of this classification, based on a literature review.

Whatever the theme considered, the limitation of data availability has often compelled data-driven approaches to focus on agricultural practices and hence on means-based indicators. Indeed, model-based and effect-based indicators require context-specific data, such as climatic or soil characteristics, or specific on-site measurements that are not measurable in such a context. A possible solution for this situation may be to use average data, for a region or a sector, but it is not relevant for all indicators. Moreover, such average data are not always available. Nevertheless, some intermediate emission indicators, such as the nitrogen balance, could be interesting because they offer a compromise between environmental relevance and measurability (Chardon 2008).

\subsection{Economic sustainability}

Economic sustainability is defined as the economic viability of farming systems, i.e., their ability to be profitable (Gómez-Limón and Sanchez-Fernandez 2010; Sadok et al. 2008; van Calker et al. 2007; Van Cauwenbergh et al. 2007) in order "to provide prosperity to the farming community" (Van Cauwenbergh et al. 2007). Economic sustainability is linked with the social pillar since income level is important for access to social activities (Van Cauwenbergh et al. 2007). The most commonly used economic indicators refer to a farm's profitability, i.e., farm income, efficiency, and productivity. Nevertheless, additional economic indicators can be grouped into three other objectives (Guillaumin et al. 2007): (1) autonomy of the farming system vis-à-vis external inputs, such as feed concentrates or mineral fertilizers, subsidies, and external financing; (2) diversification of agricultural income, through food production, non-food production (e.g., agritourism), and marketing, as well as diversification of non-agricultural activities; and (3) a farm's durability over time, mainly related to succession and transmission (Figs. 2 and 5). Indicators referring to these 


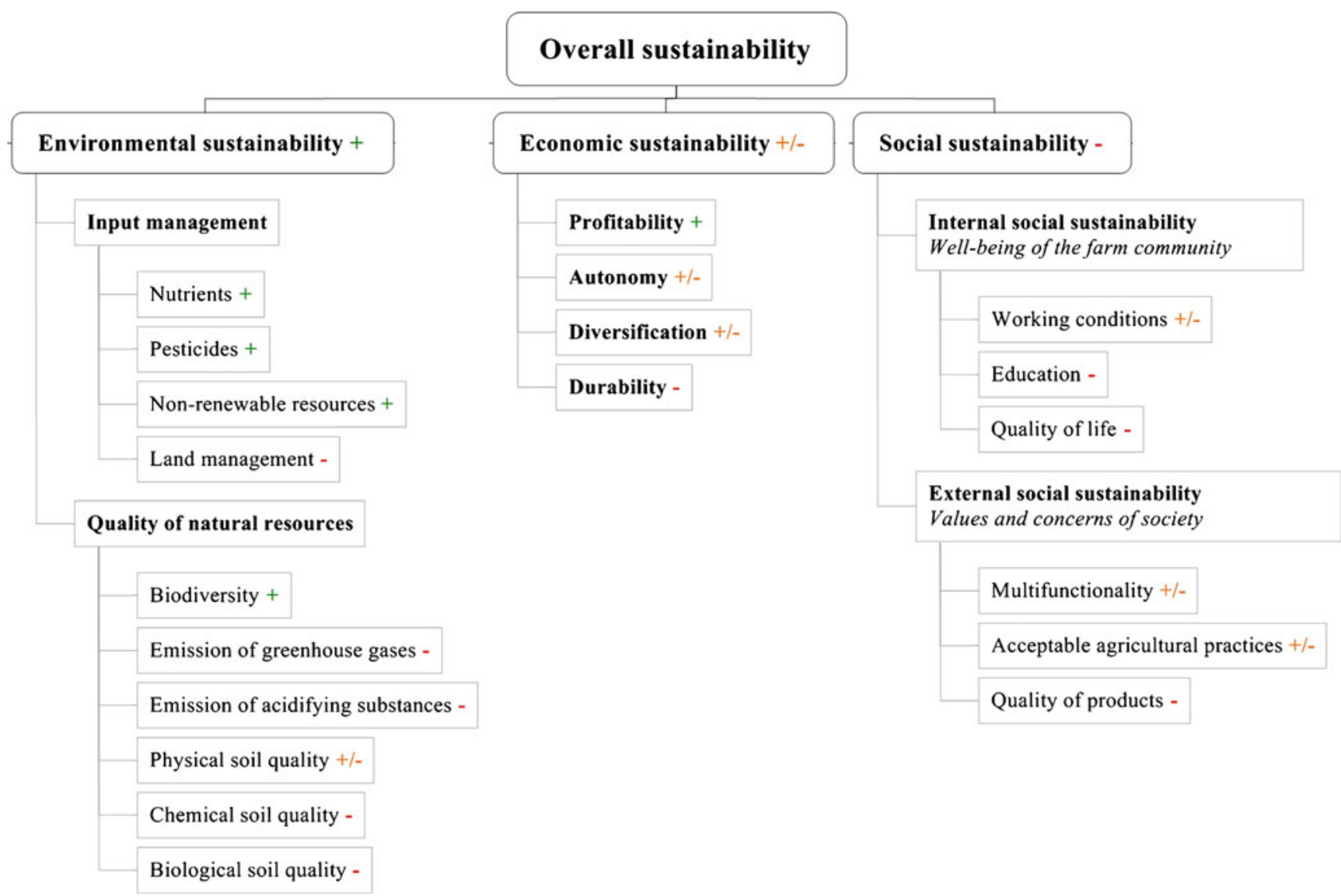

Fig. 2 Assessment of agricultural sustainability at farm level by considering environmental, economic, and social dimensions, and dividing them into various themes, based on a review of sustainability indicators. In the literature, sustainability assessments often focus on the environmental dimension, without always taking into account

objectives evaluate the farm's adaptability to changes of external context (e.g., price of agricultural products, price of energy and other inputs). Generally speaking, economic indicators are mainly quantitative, expressed in monetary terms or as ratios, even if, in some assessment methods, indicators are scored according to reference scales (CIVAM 2010; Solagro 2006; Vilain 2008).

\subsection{Social sustainability}

Little is available in the way of literature on the quantification of social sustainability, due to its subjective character, differences between farmers and other social groups in the way it is perceived (van Calker et al. 2007), and the limited availability of required data. Social sustainability is defined at two levels (Guillaumin et al. 2007; van Calker et al. 2007; Van Cauwenbergh et al. 2007): (1) at farm community level, internal social objectives are related to the well-being of the farmer and his family, i.e., their quality of life, physical, and psychological well-being; and (2) at the level of society, economic and social sustainability. A greater diversity of environmental indicators than economic or social ones also exists in the literature. ,$++/-,-$ : relative consideration of these dimensions and relative availability of existing farm-level indicators for each theme

external social objectives are related to society's demands, depending on its values and concerns, which are constantly changing. That is why the definition of this dimension is also constantly in flux. According to these aspects, indicators reviewed in the literature have been grouped into three internal objectives: education, working conditions, and quality of life, and three external objectives: multifunctionality, acceptable agricultural practices, and quality of products (Figs. 2 and 6).

Social indicators have been classified into quantitative and qualitative types. Qualitative indicators consist of selfevaluations by the farmer, for example about his quality of life (Vilain 2008). Due to data availability, such indicators requiring the farmer's opinions about specific concerns cannot be included in data-driven approaches. Quantitative indicators include: (1) raw data, i.e., with the lowest aggregation level, such as workforce and farmer qualifications (Dantsis et al. 2010; Fernandes and Woodhouse 2008); (2) simple indicators, i.e., combinations of raw data (CORPEN 2006), such as the importance of agritourism in the turnover 


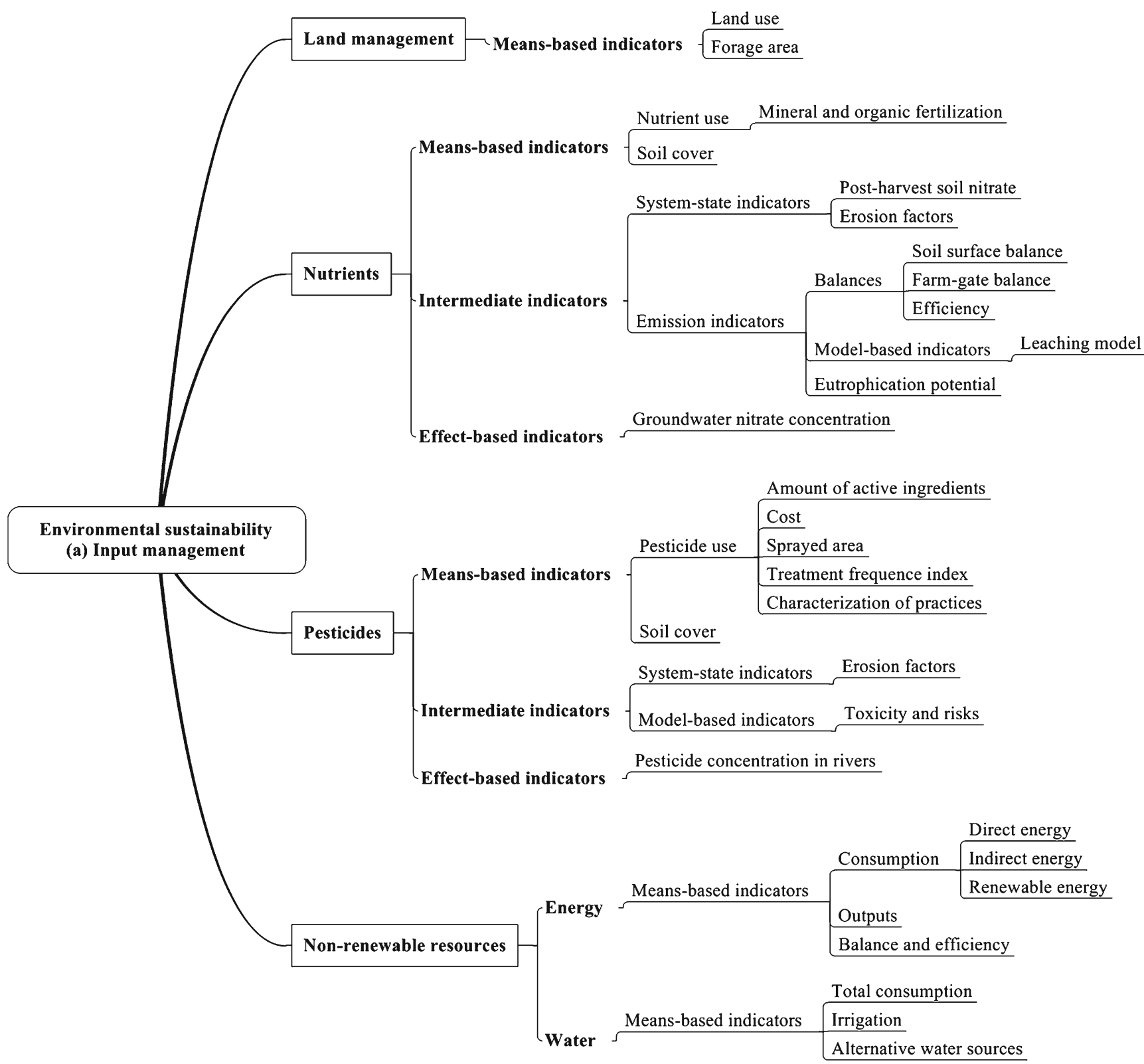

Fig. 3 Classification of environmental indicators related to input management, according to the typology based on the causal chain between practices and their environmental impacts. A great diversity of

of the farm (Guillaumin et al. 2007); and (3) composite indicators, i.e., aggregating data or indicators (CORPEN 2006), such as the animal welfare index, which is calculated from several variables: grazing period, barn surface, and freedom of movement (Sauvenier et al. 2005). There is a duality between raw data and composite indicators. On the one hand, raw data are easily measurable but provide little information. On the other hand, composite indicators summarize and simplify complex systems, but usually require specific data collection. They might also involve a loss of information because they can hide valuable information (CORPEN 2006; Riley 2001b). indicators exists for themes related to nutrients, pesticides, and nonrenewable resources, while few indicators in relation with land management were found in the literature

\section{Selection of sustainability indicators}

Indicator selection is an important step in all indicator-based assessments since it influences conclusions. The use of a well-defined and transparent procedure is thus necessary to enhance credibility and reproducibility of the evaluation (Niemeijer and de Groot 2008). As mentioned by Dale and Beyeler (2001), "a lack of robust procedures for selecting indicators makes it difficult to validate information provided by those indicators." The selection of sustainability indicators in data-driven approaches includes three main steps: (1) contextualization of the assessment; (2) comparison of 


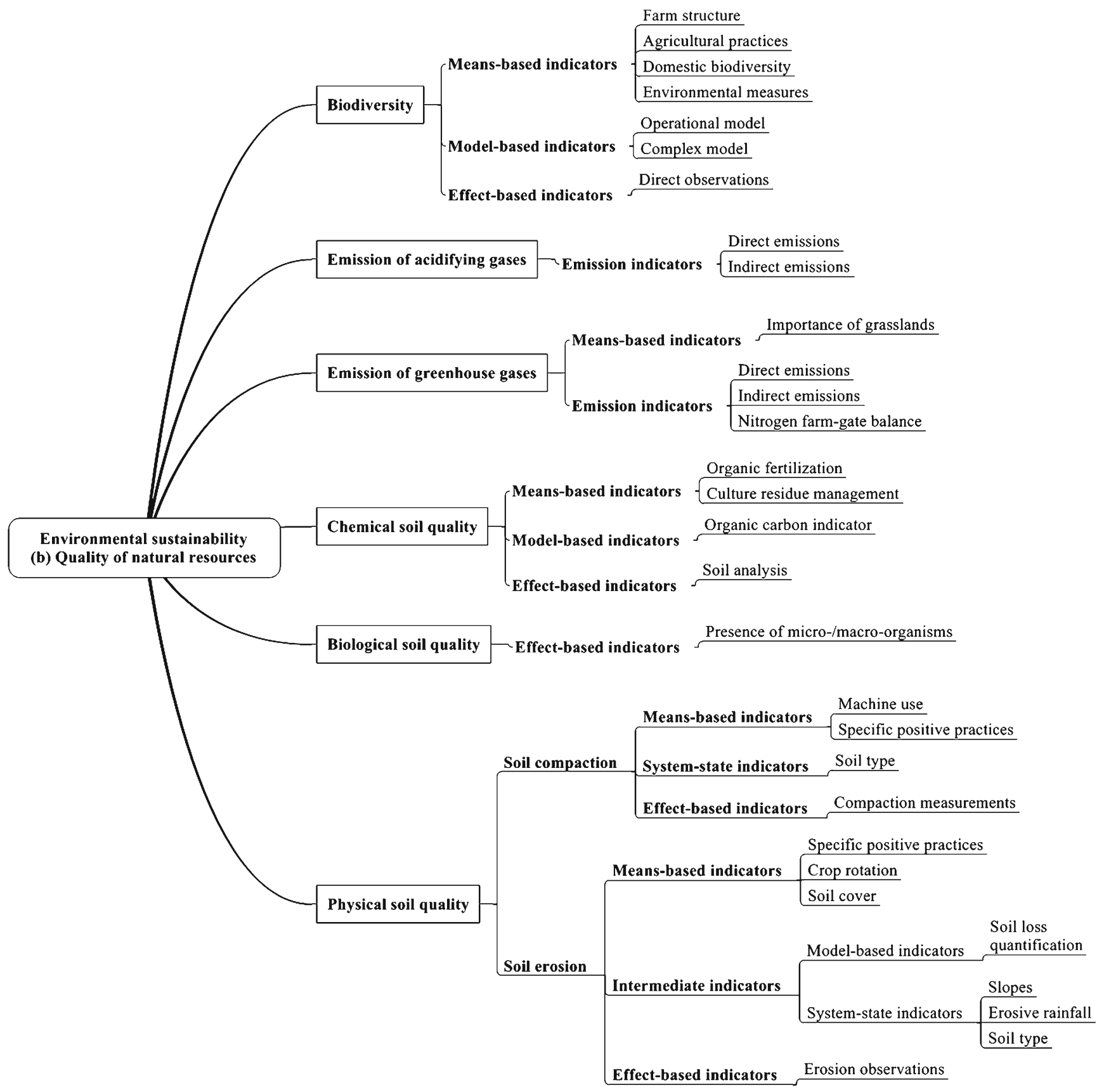

Fig. 4 Classification of environmental indicators related to quality of natural resources, according to the typology based on the causal chain between practices and their environmental impacts. Quality of natural

indicators based on various criteria, the most limiting being data availability; and (3) selection of a minimal, consistent, sufficient, and representative set of indicators.

\subsection{Contextualization}

Contextualization, also called "preliminary choices and assumptions" by Bockstaller et al. (2008), consists of defining the purpose of the analysis. For instance, an assessment resources includes themes related to biodiversity, air and soil quality. Water quality is not represented here since indicators for this theme mainly concern pesticide and nutrient use

can be performed ex ante or ex post, for research purposes, or with an advisory, decision-making, monitoring, communication or educational objective (Bockstaller et al. 2008; CORPEN 2006; Halberg et al. 2005a; Singh et al. 2009). Based on this objective, the system considered has to be defined, along with spatial and temporal analysis scales (Binder et al. 2010; Bockstaller et al. 2008). Defining the sustainability concept and setting objectives is another challenge that will influence the selection of indicators. This 


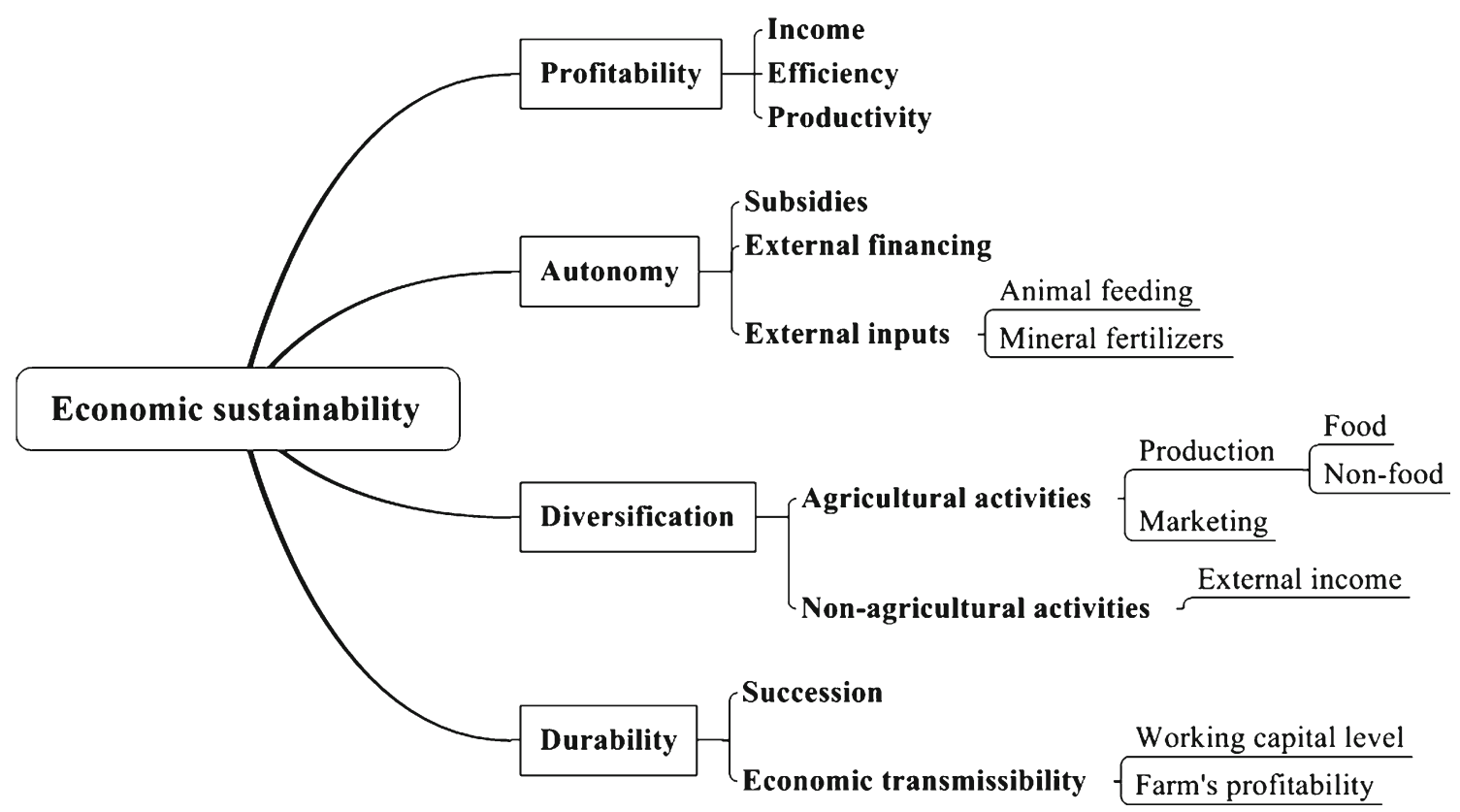

Fig. 5 Classification of economic indicators. In addition to indicators of profitability, economic indicators of autonomy, diversification, and durability evaluate the farm's adaptability to changes of external

process involves normative choices since some problems are deemed more important than others, depending on context and local perceptions (Halberg et al. 2005a). This preliminary stage also includes determining which stakeholders will be involved and how they will play a role in the assessment. Indeed, a participative process is essential for defining sustainability concept, and selecting context. Most economic indicators are quantitative, expressed in monetary terms or as ratios

objectives and the set of indicators that reliably represent the system considered (Binder et al. 2010; Ramos and Caeiro 2010). Furthermore, it is important to specify the type of end users of the assessment since it is unlikely that the same indicators will be chosen if the end users are scientists, farmers, decision makers, or consumers (Bockstaller et al. 2008).

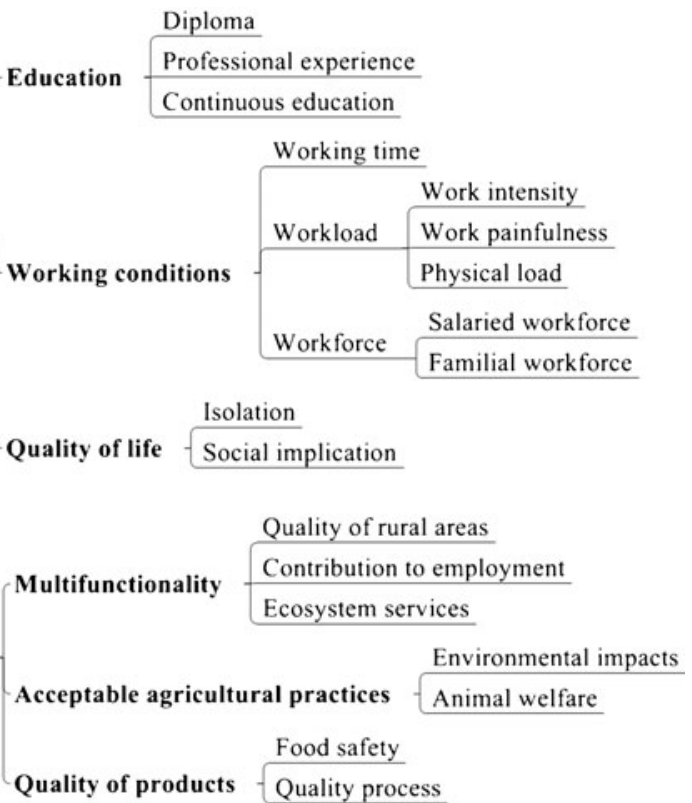

society's demands. Social indicators can be qualitative, such as selfevaluations by the farmer, or quantitative, with different levels of aggregation, ranging from raw data to composite indicators
Fig. 6 Classification of social indicators. Social dimension includes an internal social dimension that relates to the well-being of the farmer and his familiy, as well as an external social dimension concerning 


\subsection{Comparison and evaluation of indicators}

Selection criteria aim to compare and evaluate indicators found in the literature in order to formalize the process of selection in a transparent way. Various selection criteria are used in sustainability assessments, and the importance given to each depends on the context and the objective of the study (CORPEN 2006). Furthermore, the precise meaning of these criteria, such as "feasibility" or "relevance," sometimes varies between authors, highlighting a lack of common methodology to compare indicators (Bockstaller et al. 2009). The most common selection criteria used in sustainability assessments have been grouped into three classes (based on CORPEN 2006): (1) relevance: criteria related to the appropriateness of the indicators in terms of context and quality of the analysis; (2) practicability: criteria related to the practical nature of indicator calculation and implementation; and (3) end user value: criteria related to the use of the indicators by end users (Table 2).

\subsubsection{Relevance}

With regard to the contextualization of the assessment, selected indicators must correspond to the objective, the system considered, and the scales of the analysis. Concerning the spatial scale, sustainability assessments in agriculture are performed at regional, farm, or cropping system level
(Bockstaller et al. 2009). The farm is the main organization and management level, where decisions, strategic choices, and technical actions are performed (Chardon 2008; CORPEN 2006; Van Cauwenbergh et al. 2007), which is why improvements in terms of sustainability are possible at this level (Chardon 2008). A farm's boundaries can exclusively be limited to the farm or can include upstream activities, e.g., production and transport of inputs, and/or offstream activities, e.g., packaging and waste management (Bockstaller et al. 2008).

With respect to the temporal scale, indicators are used to monitor the state of the farming system at several moments in time or to compare it against a reference value (Van Cauwenbergh et al. 2007). In the first case, due to the dynamic properties of agricultural systems, one-off measures are often not accurate and indicators have to be measured with a frequency (e.g., annual, medium term, long term) that highlights a significant variation in indicator values and the influence of certain parameters, such as climate or market prices (CORPEN 2006; Van Cauwenbergh et al. 2007). In such cases, indicator values should be interpreted by considering all potential factors of influence (CORPEN 2006). As for comparison against a reference value, indicators must integrate the variability caused by external factors. For instance, due to high interannual variability, economic indicators are often calculated based on a 3-year average (Van Cauwenbergh et al. 2007; Vilain 2008).
Table 2 Criteria for the evaluation of sustainability indicators and for the selection of an appropriate set of indicators, in relation with analysis objectives

Evaluation criteria used in sustainability assessments are related to the indicator relevance in terms of context and quality of the analysis, their practicability of calculation and implementation, and their value for end users

\begin{tabular}{|c|c|c|c|}
\hline \multicolumn{3}{|c|}{ Selection criteria } & \multirow{2}{*}{$\begin{array}{l}\text { Description } \\
\text { Appropriate for the context and the objectives }\end{array}$} \\
\hline \multirow{14}{*}{$\begin{array}{l}\text { Evaluation } \\
\text { criteria }\end{array}$} & \multirow[t]{5}{*}{ Relevance } & Context and objectives & \\
\hline & & Scales of analysis & Appropriate for spatial and temporal scales \\
\hline & & Validity & Submitted to a validation process \\
\hline & & $\begin{array}{l}\text { Analytical } \\
\text { soundness }\end{array}$ & $\begin{array}{l}\text { Quality of the indicator design and the information } \\
\text { provided by the indicator output }\end{array}$ \\
\hline & & Social validation & Recognition by end users \\
\hline & \multirow[t]{4}{*}{ Practicability } & Measurability & Method of calculation and data availability \\
\hline & & Quantification & Quantitative \\
\hline & & Compatibility & Compatible with selected aggregation method \\
\hline & & Transferability & Relevant for different farm types \\
\hline & \multirow{5}{*}{$\begin{array}{l}\text { End user } \\
\text { value }\end{array}$} & Ability to summarize & Capable of simplifying and summarizing processes \\
\hline & & Comprehensibility & Clear, readable, and easy for users to interpret \\
\hline & & Reference values & Availability of reference values \\
\hline & & Policy relevance & Related to policy measures \\
\hline & & Leeway & Can be influenced by the farmer \\
\hline \multirow{4}{*}{\multicolumn{2}{|c|}{ Set of indicators }} & System representation & Comprehensive and reliable system representation \\
\hline & & Parsimony & No redundancy \\
\hline & & Consistency & Complementarity for an appropriate interpretation \\
\hline & & Sufficiency & Integration of all sustainability objectives \\
\hline
\end{tabular}


Concerning the quality of analysis, validity includes analytical and social aspects. The analytical aspect is related to the analytical soundness of the indicator, i.e., is the indicator scientifically substantiated and does it provide reliable information in relation to the phenomenon to be monitored? The social aspect concerns recognition of the indicator by stakeholders, i.e., is the indicator meaningful and accepted by users? (Bockstaller and Girardin 2003; Fernandes and Woodhouse 2008; Meul et al. 2009; Sauvenier et al. 2005) With respect to the first aspect, some authors talk about robustness, i.e., insensitivity to interference (CORPEN 2006; Niemeijer and de Groot 2008), sensitivity to stresses, external changes, and changes to the system (Meul et al. 2008; Niemeijer and de Groot 2008; Sauvenier et al. 2005), reproducibility (Dantsis et al. 2010) or, more generally, statistical properties. These properties have to allow an unambiguous interpretation of the indicator (Niemeijer and de Groot 2008). To evaluate validity of indicators, CloquellBallester et al. (2006) also proposed a criteria hierarchy and a methodology using notions of conceptual coherence, operational coherence, and utility of indicators. Concerning the social aspect, the usefulness of indicators for end users depends on the context of the analysis and should be studied in interaction with stakeholders, for example using a survey to point up their strengths and weaknesses, to check they have been understood and interpreted properly, and to evaluate the willingness of end users to use them in practice (Bockstaller and Girardin 2003; Meul et al. 2009).

\subsubsection{Practicability}

Measurability concerns the availability of required data to calculate indicators and the method of calculation used. Indicators should be calculated from data that are easily obtainable, i.e., directly from farmers or from existing databases, or collected at a reasonable cost and within a reasonable time span (Bechini and Castoldi 2009; Dantsis et al. 2010; Fernandes and Woodhouse 2008; Gómez-Limón and Sanchez-Fernandez 2010; Sauvenier et al. 2005). In datadriven approaches, data availability is the first filter applied in the selection process since indicators must be calculated from existing databases.

Some authors also recommend using indicators that are quantifiable in an objective way, as values rather than as scores (van Calker et al. 2007; van der Werf and Petit 2002). Indeed, scores have no dimension units and cannot therefore be compared with other values or observations (van der Werf and Petit 2002). Other authors justify this criterion by the need to use indicator outputs in a model (van Calker et al. 2007).

When indicators are aggregated at a later stage, they have to be compatible with the chosen aggregation method. For instance, if indicators are integrated into a multi-attribute sustainability function, it must be possible to determine utility values for selected indicators (van Calker et al. 2006; van Calker et al. 2007). Furthermore, indicators included in an assessment method should be transferable, for example with respect to different types of farm, to enable this method to be used in different areas and situations (Niemeijer and de Groot 2008; Sauvenier et al. 2005). Consequently, identifying common indicators is a challenge in order to compare studies easily (Riley 2001b).

\subsubsection{End user value}

The appropriateness of indicators in line with the expectations of stakeholders is required in a sustainability assessment. Indicators have to be clear, readable, and easy for end users to understand and interpret (Bechini and Castoldi 2009; CORPEN 2006; Dantsis et al. 2010; Meul et al. 2008). By definition, an indicator is a compromise, providing significant information and simplifying complex processes (Bechini and Castoldi 2009; Rigby et al. 2001). Aggregated and simplified information, such as composite indicators, promotes the function of communication (CORPEN 2006). However, relevance of aggregation is often discussed because of the loss of information and the methodological problems involved, the subjectivity of component weighting, and the difficulty of defining reference values (Riley 2001b; Bockstaller et al. 2008). Moreover, it does not enable us to understand the complexity and tradeoffs between its components (Castoldi and Bechini 2010). In this context, sensitivity analyses are interesting to evaluate the consequences of weighting and to deal with trade-offs between components of a composite indicator (Bockstaller et al. 2008). Bockstaller et al. (2008) therefore recommend the joint use of aggregated and individual indicators.

Reference values define the appropriate level of sustainability for an indicator. They aim to evaluate indicator values and to help users interpret them (Bockstaller et al. 2008; Meul et al. 2008; Van Cauwenbergh et al. 2007). They can be (1) absolute fixed values, such as thresholds, i.e., minimum or maximum acceptable values, or targets, i.e., values identifying desirable conditions, or (2) relative values, i.e., comparison of indicator values with initial value, average of the sample, regional average, desirable trends, or between sectors (Bockstaller et al. 2008; CORPEN 2006; Van Cauwenbergh et al. 2007). Absolute values can be scientific values, legal norms (Van Cauwenbergh et al. 2007), or values defined by stakeholders (Bockstaller et al. 2008). They involve the determination of a reasonable level for a given farm, depending on the context and the system (Halberg et al. 2005b). Relative values allow us to avoid the choice of an absolute value. They enable farms to be compared but do not determine whether they are sustainable (Bockstaller et al. 2008). For some authors, the existence of historical comparative data for the indicator is then an 
additional criterion for selecting indicators (Niemeijer and de Groot 2008). Another solution involves scoring indicators, using a relative scale (Van Cauwenbergh et al. 2007), but this might make it more complex for the farmer to understand how to improve the objective related to the indicator (Halberg et al. 2005b). In terms of interpretation, the meaning of scores must be clearly specified: does it represent a risk, an impact, an environmental performance, a negative or a positive effect (Bockstaller et al. 2008)?

Some criteria are used in specific contexts. From a policy point of view, indicators should address important issues for policy makers (Fernandes and Woodhouse 2008; Sadok et al. 2009), monitor the effects of policy measures, and identify whether action is needed (Gómez-Limón and SanchezFernandez 2010; Sauvenier et al. 2005). For a farm's diagnosis, the farmer should have leeway on the value of the indicator (van Calker et al. 2007). Table 3 gives an example of the evaluation of nitrogen indicators, based on some of these three kinds of selection criteria.

\subsection{Selection of a set of indicators}

In addition to these diverse selection criteria, indicators have to be considered as a set, rather than on an individual basis (Lyytimäki and Rosenström 2008). Indeed, for a correct interpretation, an indicator needs to belong to a consistent and comprehensive set (Niemeijer and de Groot 2008). The challenge is to select a set of indicators able to comprehensively and reliably represent the complexity of the system, its current environmental, economic, and social state, and its transition towards sustainability (Binder et al. 2010). From a practical point of

Table 3 Description and comparison of four indicators related to nitrogen management, on the basis of selection criteria concerning relevance, practicability, and end user value of these indicators

\begin{tabular}{|c|c|c|c|c|c|c|}
\hline & & $\begin{array}{l}\text { Mineral nitrogen } \\
\text { fertilization }\end{array}$ & $\begin{array}{l}\text { Livestock } \\
\text { stocking rate }\end{array}$ & Nitrogen surplus & $\begin{array}{l}\text { Nitrogen indicator (IN) } \\
\text { (Bockstaller et al. 2008) }\end{array}$ & $\begin{array}{l}\text { Groundwater nitrate } \\
\text { concentration }\end{array}$ \\
\hline \multirow[t]{3}{*}{ Description } & Definition & $\begin{array}{l}\mathrm{N} \text { mineral fertilizers } \\
\text { inputs }\end{array}$ & $\begin{array}{l}\text { Density of livestock } \\
\text { on the forage area }\end{array}$ & $\begin{array}{l}\text { Difference between } \\
\mathrm{N} \text { inputs entering } \\
\text { and } \mathrm{N} \text { outputs } \\
\text { leaving the farming } \\
\text { system }\end{array}$ & $\begin{array}{l}\text { Output of a model } \\
\text { simulating } \mathrm{NO}_{3}^{-} \\
\text {leaching and } \mathrm{NH}_{3} \text {, } \\
\mathrm{N}_{2} \mathrm{O} \text { emissions }\end{array}$ & Direct measurement \\
\hline & Unit & Kilogram N/hectare & $\begin{array}{l}\text { Livestock units/ } \\
\text { hectare }\end{array}$ & $\begin{array}{l}\text { Kilogram N/hectare } \\
\text { or kilogram N/kilogram } \\
\text { product }\end{array}$ & Scores & Milligrams $\mathrm{NO}_{3}{ }^{-} /$liter \\
\hline & Type & Means-based & Means-based & Emissions (balance) & $\begin{array}{l}\text { Emissions } \\
\text { (model-based) }\end{array}$ & Effect-based \\
\hline \multirow[t]{11}{*}{ Evaluation } & Relevance & & & & & \\
\hline & Temporal scale & Annual & Annual & Annual-Monitoring & Annual, rotation & Monitoring \\
\hline & Spatial scale & $\mathrm{P} / \mathrm{F}$ & $\mathrm{F}$ & $\mathrm{F}$ & $\mathrm{P} / \mathrm{F}$ & Watershed/R \\
\hline & Practicability & & & & & \\
\hline & Validity & $\begin{array}{l}\text { Weak link with the } \\
\text { environmental } \\
\text { impact, not to be } \\
\text { used alone and } \\
\text { for a single year } \\
\text { (CORPEN 2006) }\end{array}$ & $\begin{array}{l}\text { Literature } \\
\quad \text { (Vilain 2008) }\end{array}$ & $\begin{array}{l}\text { Literature (Thomassen } \\
\text { and de Boer 2005; } \\
\text { Vilain 2008) }\end{array}$ & $\begin{array}{l}\text { Literature (Bockstaller } \\
\text { et al. 2008) }\end{array}$ & $\begin{array}{l}\text { Direct link with the } \\
\text { environmental impact }\end{array}$ \\
\hline & Data availability & ++ & ++ & + & - & - \\
\hline & $\begin{array}{l}\text { Quantitative/ } \\
\text { qualitative }\end{array}$ & Quantitative & Quantitative & Quantitative & $\begin{array}{l}\text { Quantitative } \rightarrow \\
\text { qualitative }\end{array}$ & Quantitative \\
\hline & End user value & & & & & \\
\hline & $\begin{array}{l}\text { Ability to } \\
\text { summarize }\end{array}$ & - & - & + & ++ & ++ \\
\hline & Reference values & $\begin{array}{l}\text { Regional, sectoral } \\
\text { reference }\end{array}$ & $\begin{array}{l}\text { Regional, sectoral } \\
\text { reference }\end{array}$ & $\begin{array}{l}\text { Regional, sectoral } \\
\text { reference }\end{array}$ & $\begin{array}{l}\text { Scores } 0-10(10=\text { no } \\
\text { losses, acceptable } \\
\text { value from } 7)\end{array}$ & 50 milligrams $\mathrm{NO}_{3}^{-} /$liter \\
\hline & Farmer's leeway & ++ & + & + & $+1-$ & - \\
\hline
\end{tabular}

Indicators have then to be selected by considering this comparison, but also the objectives and scales of the analysis and the characteristics of the set of indicators

$N$ nitrogen; $\mathrm{NO}_{3}{ }^{-}$nitrates; $\mathrm{NH}_{3}$ ammoniac; $\mathrm{N}_{2} \mathrm{O}$ nitrous oxide; $P$ parcel level; $F$ farm level; $R$ regional level;,,$++++/-,-,--$ relative degree of availability, ability to summarize, and possibility for the farmer to influence the output value 
view, three criteria have to be met. (1) Parsimony: selected indicators are not redundant and are few in number to ensure readability and manageability (Binder et al. 2010; Sadok et al. 2009). (2) Consistency: all indicators necessary for the interpretation are included in the selected set. For instance, it is recommended that the indicator of mineral nitrogen input should be considered with application period, application methods, and yields (CORPEN 2006). (3) Sufficiency: the set of indicators is exhaustive to include all sustainability objectives (Binder et al. 2010; Sadok et al. 2009) (Table 2).

Taking into account interactions between indicators makes it possible to appropriately represent the main structure and processes of the system (Binder et al. 2010). Trade-offs occur when several indicators cannot all be improved at the same time (Halberg et al. 2005a). For example, Darnhofer et al. (2010) highlight the trade-off existing between the short-term economic efficiency of a farm and the objective of adaptability by developing diverse activities that ensure the farm's longterm viability. In order to take into account interactions between environmental themes and indicators, Niemeijer and de Groot (2008) propose a selection process, focusing on the environmental dimension, based on the concept of a causal network, i.e., a network of multiple causal chains, including interactions between them. For instance, to assess the environmental impact of nitrogen fertilization on surface water ecosystems, selection is made by considering a network composed of causal chains related to crop production, socioeconomic issues, air, soil, and water (Niemeijer and de Groot 2008).

Furthermore, identification of correlations between indicators could also help the user in the process of selecting a minimal, consistent, and sufficient set of indicators. By way of illustration, Thomassen and de Boer (2005) found, in commercial dairy farms in the Netherlands, a correlation between nitrogen surplus and eutrophication potential onfarm, meaning that the nitrogen surplus is relevant "to $a$ moderate extent" to assess the environmental impact of eutrophication with more easily available data. Although nitrogen surplus is used in various assessments (Bechini and Castoldi 2009; Gómez-Limón and Sanchez-Fernandez 2010; Meul et al. 2008; Vilain 2008), this indicator is considered a poor predictor of nitrogen losses, especially on the scale of a single year (Buczko and Kuchenbuch 2010).

\section{$4 \mathrm{Key}$ issues involved in the assessment}

\subsection{Gaps in the sustainability assessment}

In data-driven approaches, data availability is a significant constraint for selection and calculation of indicators. Therefore, by comparing the overview of sustainability themes with themes that can be assessed from available data, some gaps in the assessment can be highlighted. Because they require few data for their calculation and because they are based on farmers' practices, most means-based indicators and some intermediate indicators, such as nutrient surplus, can be used to assess environmental themes in data-driven approaches. However, such indicators are not available for all themes. For instance, assessment of greenhouse gas emissions involves indicators requiring a lot of detailed data, e.g., grazing period, manure storage, and animal feeding. Most economic indicators can be assessed because they require quantitative monetary data that are usually recorded, for instance in farm accountancy databases. However, indicators relating to themes like product marketing or external income require data that are probably less commonly recorded as a matter of routine. Finally, social themes are clearly difficult to assess without collecting additional data on the farm. In fact, social indicators often depend on qualitative estimations. Consequently, only raw data, such as working time, workforce, and education, and some indicators with a low degree of aggregation could be used as social indicators.

These gaps also involve imbalance between dimensions and themes, with regard to their development and consideration in the literature (Fig. 2). This imbalance can be explained by two factors. Firstly, the interest of stakeholders (e.g., civil society, researchers, and agricultural policy makers) is currently mainly focused on environmental issues. Secondly, the environmental dimension covers large and complex fields, whereas the economic dimension is comprehended in a less holistic manner due to the monetary nature of this criterion (Sadok et al. 2009). The social dimension spans an intermediate number of themes (Sadok et al. 2009). However, few sustainability assessments consider this dimension due to its impracticability and the difference in perception between stakeholders (Van Calker et al. 2007).

Two suggestions are made to deal with these shortcomings. First, any gaps highlighted should be explicitly mentioned in the results of the assessment. Second, gaps and limitations of data-driven approaches should be taken into account for further collection of data in order to reduce imbalances between topics, as well as to provide information about the topics on which more research is needed. It concerns for instance the development of farm-level social and socioeconomic indicators, among others indicators related to durability, working conditions, and quality of life. With regard to work organization, Hostiou and Dedieu (2012) developed, for example, a method for assessing work productivity and flexibility in livestock farms. Such works about social dimension of agriculture would have to be developed in order to restore the balance between sustainability dimensions. 


\subsection{Use of means-based indicators}

Due to the limitation of data availability, data-based approaches are often restricted to mainly considering means-based indicators to assess the environmental dimension. However, as mentioned in section 2.1, these indicators have a low quality of prediction of environmental impacts. Hence, one solution to increase their accuracy might involve using a combination of indicators for the same theme (Bockstaller et al. 2008). For example, the indicator of catch crops area has to be considered with bare soils area, bare soils duration, and the period during which there is a high risk of leaching (CORPEN 2006) to respect the consistency of the set of indicators. However, increasing the number of indicators is complicated in practice (Bockstaller et al. 2008) as it causes redundancy in the set of indicators and makes interpretation and communication of the results more difficult. It also involves the development and use of an aggregation procedure.

Furthermore, some indicators, such as energy consumption, are calculated from several inputs. Data necessary for calculating these components are not always available in the case of data-driven approaches, however. In this case, the use of simplified indicators could be of interest to select a set of indicators. By way of illustration, four main inputs (electricity, fuel, mineral fertilization, and animal feeding) can be considered to assess fossil energy use in herbivore livestock farming systems since it has been shown that they represented $80 \%$ of the energy consumed. The remaining $20 \%$ mainly relates to machines and buildings, for which there is little leeway for the farmer in the medium term, and to pesticides, which represent less than $2 \%$ of the energy consumed (Beguin et al. 2008). This example underlines the need for a sensitivity analysis to identify input variables having a significant effect on outputs values (Bockstaller et al. 2008). Thereafter, we can focus on these significant variables to develop simplified indicators.

\subsection{Choice of functional units}

The outputs of quantitative environmental indicators generally increase with the size of the farm. Functional units are therefore used in order to compare farms (Chardon 2008; Thomassen et al. 2008). These are defined according to the two main functions that are commonly assigned to agricultural systems: (1) the expression of impacts per amount of product (e.g., liter of milk, kilogram of meat) is related to the function of market goods production; and (2) the expression per hectare of agricultural land refers to the function of non-market goods production, such as environmental services (Basset-Mens and van der Werf 2005). Less frequently, the function aiming to provide an income for the farmer is taken into account, defining a third functional unit that consists of expressing impacts per income unit (van der Werf et al. 2009).

The choice of functional unit depends on the objective and context of the evaluation (van der Werf et al. 2011), but also influences the relative position of farms (Chardon 2008). For instance, a comparison between organic and conventional milk production systems gives different results, depending on the functional unit used: environmental impacts per hectare are generally lower for organic farms, but the impacts are fairly equivalent in both systems when they are expressed per unit of product (Halberg et al. 2005a; van der Werf et al. 2011).

Some authors recommend selecting indicators that can be expressed per amount of product and per hectare in order to evaluate the systems according to both functions (van der Werf and Petit 2002; van der Werf et al. 2011). For others, indicators concerning global impacts, e.g., greenhouse gas emissions, should be expressed per unit of product, while indicators related to local impacts, e.g., eutrophication potential, should be expressed per hectare (Halberg et al. 2005a). Indeed, lower emissions of extensive systems are beneficial on a local scale but, if lower production has to be compensated by more intensive production in other regions, global emissions may be the same or higher. It is therefore interesting to express global impacts per unit of product (Halberg et al. 2005a).

On the other hand, in the case of mixed farms combining several types of productions, such as milk, meat, and crops, expressing indicators per unit of product is a challenge in terms of allocation between the different types (Chardon 2008). Such allocations can be made, for example, according to the economic value of the products (Basset-Mens and van der Werf 2005), or their nutritional value in terms of protein or energy (Chardon 2008).

\subsection{Use of indicators to compare systems}

In some cases, the goal of the assessment is to compare the sustainability of different farming systems, for instance between organic and conventional dairy farming systems. Not all indicators are suitable for making such comparisons, however. Conditions for use and interpretation of indicators should thus be considered during the selection stage. For instance, nutrient balances can be used to compare farms only if they have a comparable production type (e.g., arable versus livestock) and intensity (e.g., milk production per hectare) (Nevens et al. 2006). The relationship between nutrient surplus and environmental losses is in fact exclusively valid within a given production system (Chardon 2008). To take another example, economic criteria have to be interpreted by taking into account the farm life cycle and the production system. For instance, the solvency rate is 
usually lower for new young farmers than for their older counterparts (Guillaumin et al. 2007).

\section{Selection of indicators to analyze the sustainability of Walloon dairy and beef livestock systems}

\subsection{Contextualization}

The issues reviewed in the first four sections were considered in selecting indicators in the context of the sustainability analysis of dairy and beef livestock systems in Wallonia (the southern part of Belgium). The purpose of this research is to analyze diversity of a set of dairy farms and a set of beef farms, based on economic, environmental, and social indicators. Indicators were calculated based on data derived from two regional farm accounting databases (Agricultural Economic Analysis Department 2008 and 2009; Walloon Breeders Association 2008 and 2009). The spatial scale is the farm level, while the temporal scale is annual, due to accounting data characteristics. Stakeholders involved in the assessment are farmers, the farmers' union, researchers, and commercial players, such as milk dairies, cheese dairies, or slaughterhouses, who will be interviewed to take into account their definition of sustainability and to internally validate the selected set of indicators.

\subsection{Selection process}

The selection process is described in Fig. 7. The procedure uses some of the selection criteria summarized in Table 2 (section 3) to compare indicators and to select a minimal, consistent, and sufficient set of indicators. The initial list of indicators was established by combining four steps: (1) a review of the literature aiming to list indicators and to class them by dimension, theme, and type (section 2); (2) consultation of experts in economics, nitrogen management, biodiversity, pesticides, energy consumption, and greenhouse gas emissions to evaluate the relevance of these indicators and possibly suggest some new ones; (3) an analysis of databases to identify what data are available; and (4) preliminary selection based on the criteria of appropriateness for the context and scales, analytical validity (relevance), and data availability (measurability).

Indicators were then calculated and the criterion of measurability resulted in the removal of some indicators from the list due to calculation problems related to data characteristics. For instance, missing data on water consumption for a sample of farms involved deleting this indicator to avoid any bias in the analysis. To respect the parsimony criterion for the set of indicators, an analysis of the correlations between indicators was then performed. In the case of indicators showing a coefficient of correlation higher than 0.8 and referring to the same sustainability objective, one of the pair was deleted, based on criteria of comprehensibility and ability to summarize. If such considerations were not
Fig. 7 Selection of indicators to analyze the sustainability of Walloon livestock farming systems, with a data-driven approach based on farm accounting databases. The selection process uses several criteria in order to select a set of indicators from the initial list. This process also highlights gaps, i.e., themes for which no indicators are measurable from available data, and has to be supplemented with interviews with stakeholders to validate the list of indicators

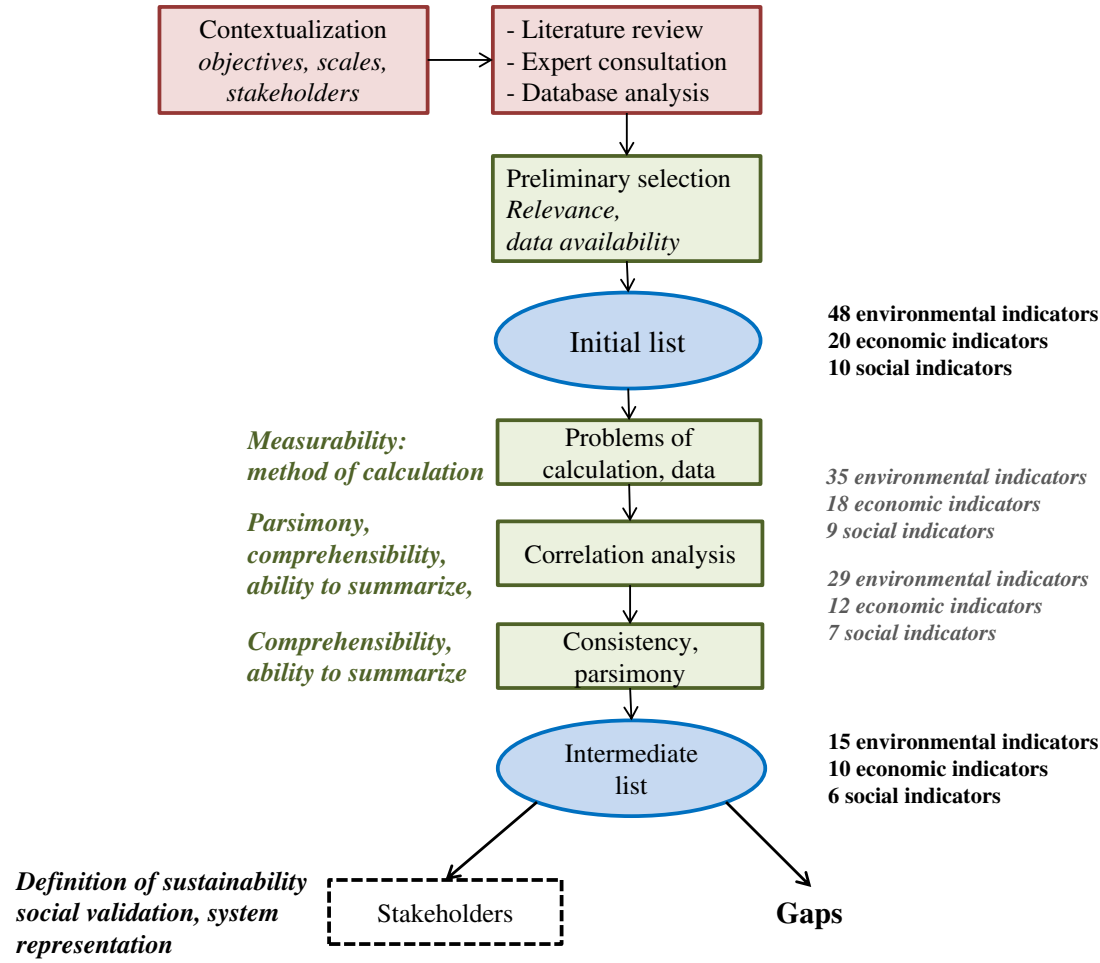


applicable, the indicator with the highest coefficient of variation was chosen since our goal is to analyze the diversity of the farms. Finally, because the set included several noncorrelated indicators representing the same sustainability objective, it was still necessary to remove some of these to obtain a non-redundant and consistent set of indicators. For this purpose, the need to consider complementary indicators for the interpretation, and the criteria of comprehensibility and ability to summarize were taken into consideration. The intermediate list of indicators resulting from this process includes 15 environmental, 10 economic, and 6 social indicators. This imbalance is related to the uneven representation of these three dimensions in the literature, but also to the exclusive use of accounting databases that mainly include economic and input-related data (e.g., fertilizers and animal feeding). As mentioned in section 5.1, the process will be supplemented with interviews with stakeholders.

The selected indicators were classified by theme, and comparison of this list with the themes reviewed in the literature and described in section 2 highlighted gaps in the assessment. Consequently, emissions of greenhouse gases and acidifying substances, soil quality, quality of life, animal welfare, workload, product quality, and landscape quality are not assessed by our set of indicators due to a lack of data regarding these topics. Other key issues, presented in section 4 , were also taken into account in the process. Firstly, for the environmental dimension, the set includes mainly means-based indicators. Simplified indicators, such as energy consumption calculated from four main topics (section 4.2), were also useful since data availability was our main constraint in this selection process. In fact, neither database had any data on agricultural machines and buildings. With regard to functional units (section 4.3), environmental indicators are mainly expressed by hectare due to problems of allocations between types of production on a farm. Indeed, farms are defined as specialized according to the European typology. Consequently, the existence of several types of production is possible on one farm. This choice of unit is advantageous for extensive systems (Schröder et al. 2003), and interpretation will consequently be performed with care. However, environmental, economic, and social indicators expressed in other units are considered in a complementary manner in further analyses. Finally, the comparison of farms based on sustainability indicators has to be done carefully (section 4.4). Interpretation of the results involves taking into account the influence of the farm's structure on some indicator outputs. For instance, the location of a farm in Wallonia determines soil and climatic conditions. Such conditions influence the presence of cash crops on the farm and consequently have an impact on pesticide costs. To manage this aspect, structure indicators, such as percentage of grasslands or percentage of cash crops in the utilized area, are considered in interpreting results.
In conclusion, the overview of sustainability themes and indicator typology (section 2), the summary and description of steps and criteria involved in a process of selection (section 3), as well as the key methodological issues described (section 4) were all useful in making a relevant and transparent selection of sustainability indicators within the context of a data-driven analysis of livestock farming system sustainability.

\section{Conclusion}

Due to the multiplicity of indicators aimed at assessing the sustainability of livestock farming systems, the implementation of a transparent and documented selection process is necessary to avoid arbitrary decisions and to ensure credibility of the assessment. In this context, data-driven approaches involve selecting a set of indicators from available data. This article provides a general overview of typologies of sustainability indicators and discusses practical aspects to be implemented in the selection process.

The most developed typology concerns the environmental dimension, with a distinction made between means-based indicators, intermediate indicators, including system-state and emission indicators, and effect-based indicators. Economic and social indicators can be classified according to their quantitative or qualitative character and their degree of aggregation, ranging from raw data to composite indices. Due to the limitation of data availability, with regard to the environmental dimension, a data-driven assessment is often restricted to focusing mainly on means-based indicators, which are, in fact, based on farmers' practices and require few data for their calculation. They do, however, have a low quality of prediction for environmental impacts. Due to the same constraint, the social dimension is mainly estimated by means of raw data indicators, such as the workforce. In contrast, the economic dimension might be more easily assessed since it covers less varied themes. Moreover, data are generally available for quantitative economic indicators, for instance in farm accountancy databases.

To ensure transparency and credibility, the selection process should comprise three steps. First, contextualization consists of defining the objectives of the analysis, and temporal and spatial scales, as well as identifying stakeholders and determining their involvement. Existing indicators are then compared and evaluated based on selection criteria relating to relevance, practicability, and end user value. These criteria are summarized in Table 2. The choice of criteria depends on the context of the assessment. Finally, the selected set of indicators has to appropriately represent the system and respect the criteria of parsimony, consistency, and sufficiency.

Since data-based assessments have clear limitations, transparency of methodological issues is a prerequisite. Gaps resulting from non-availability of indicators for some themes 
should be explicitly mentioned in the results. When only means-based indicators can be used to assess an environmental theme, several indicators can be combined to increase the accuracy of the assessment. However, a compromise has to be found between such a combination and consideration of the parsimony criterion to ensure practicability in use and ease of interpretation. Some environmental indicators can be expressed in various units: per hectare, per kilo of product, or per euro of income. The choice of functional unit influences the results since relative positions of farms will be different depending on the unit used. Consequently, the choice made has to be taken into account in interpreting the results. Finally, when farms are compared from indicators, the influence of the structure on some indicator values has to be carefully studied. More generally, conditions of use and interpretation have to be considered.

Further research is needed to explore potential interactions between indicators, between and within themes and dimensions. Indeed, the use of a hierarchical framework compartmentalizes indicators into themes and dimensions and poorly reflects interactions between them. The concept of a causal network (Niemeijer and de Groot 2008), currently focusing on environmental impacts, could be broadened to consider the three dimensions equally and implemented to select indicators. Finally, the identification of imbalances and gaps in the assessment highlights the themes for which few indicators are available, and more research is needed in this area. This typically concerns social themes, non-monetary economic themes, as product marketing or external activities, and environmental themes that are less developed in the literature, e.g., soil quality and land management.

Acknowledgments The first author is a recipient of a Ph.D. grant financed by the "Fonds pour la formation à la Recherche dans l'Industrie et dans l'Agriculture" (FRIA). We thank the Agricultural Economic Analysis Department (DAEA) and the Walloon Breeders Association (AWE) for having made available the data, and two anonymous reviewers for useful comments on the earlier version of the manuscript.

\section{References}

Alkan Olsson J, Bockstaller C, Stapleton L, Ewert F, Knapen R, Therond O, Geniaux G, Bellon S, Pinto Correira T, Turpin N, Bezlepkina I (2009) A goal oriented indicator framework to support integrated assessment of new policies for agri-environmental systems. Environ Sci Policy 12:562-572. doi:10.1016/j.envsci.2009.01.012

Aveline A, Rousseau ML, Guichard L, Laurent M, Bockstaller C (2009) Evaluating an environmental indicator: case study of MERLIN, a method for assessing the risk of nitrate leaching. Agr Syst 100:22-30. doi:10.1016/j.agsy.2008.12.001

Basset-Mens C, van der Werf HMG (2005) Scenario-based environmental assessment of farming systems: the case of pig production in France. Agr Ecosyst Environ 105:127-144. doi:10.1016/ j.agee.2004.05.007

Bechini L, Castoldi N (2009) On-farm monitoring of economic and environmental performances of cropping systems: results of a 2-year study at the field scale in northern Italy. Ecol Indic 9:1096-1113. doi:10.1016/j.ecolind.2008.12.008

Beguin E, Bonnet J, Belveze J, Bellet V, Dolle JB (2008) Evaluation des consommations d'énergie dans les exploitations bovines et ovines et identification de marges de progrès. Institut de l'Elevage, Paris

Binder CR, Feola G, Steinberger JK (2010) Considering the normative, systemic and procedural dimensions in indicator-based sustainability assessments in agriculture. Environ Impact Asses 30:71-81. doi:10.1016/j.eiar.2009.06.002

Bockstaller C, Girardin P (2003) How to validate environmental indicators? Agr Syst 76:639-653. doi:10.1016/S0308-521X(02)00053-7

Bockstaller C, Guichard L, Makowski D, Aveline A, Girardin P, Plantureux S (2008) Agri-environmental indicators to assess cropping and farming systems. A review. Agron Sustain Dev 28:139 149. doi:10.1051/agro:2007052

Bockstaller C, Guichard L, Keichinger O, Girardin P, Galan MB, Gaillard G (2009) Comparison of methods to assess the sustainability of agricultural systems. A review. Agron Sustain Dev 29:223-235. doi:10.1051/agro:2008058

Boogaard BK, Oosting SJ, Bock BB, Wiskerke JSC (2011) The sociocultural sustainability of livestock farming: an inquiry into social perceptions of dairy farming. Animal 5:1458-1466. doi:10.1017/ S1751731111000371

Buczko U, Kuchenbuch RO (2010) Environmental indicators to assess the risk of diffuse nitrogen losses from agriculture. Environ Manage 45:1201-1222. doi:10.1007/s00267-010-9448-8

Castoldi N, Bechini L (2010) Integrated sustainability assessment of cropping systems with agro-ecological and economic indicators in northern Italy. Eur J Agron 32:59-72. doi:10.1016/j.eja.2009.02.003

Chardon X (2008) Evaluation environnementale des exploitations laitières par modélisation dynamique de leur fonctionnement et des flux de matière: développement et application du simulateur Mélodie. Dissertation, Institut des Sciences et Industries du Vivant et de l'Environnement, Agro Paris Tech, Paris

CIVAM (2010) Diagnostic de durabilité du Réseau Agriculture Durable. Guide de l'utilisateur 2010. www.agriculture-durable.org. Accessed 9 Mar 2011

Cloquell-Ballester VA, Cloquell Ballester VA, Monterde-Diaz R, Santamarina-Siurana MC (2006) Indicators validation for the improvement of environmental and social impact quantitative assessment. Environ Impact Asses 26:79-105. doi:10.1016/j.eiar.2005.06.002

CORPEN (2006) Des indicateurs d'azote pour gérer des actions de maitrise des pollutions à l'échelle de la parcelle, de l'exploitation et du territoire. Ministère de l'Écologie et du Développement Durable, Paris. http://www.developpement-durable.gouv.fr/IMG/pdf/ DGALN_2006_09_azote_indicateur.pdf. Accessed 4 Feb 2011

Dale VH, Beyeler SC (2001) Challenges in the development and use of ecological indicators. Ecol Indic 1:3-10. doi:10.1016/S1470160X(01)00003-6

Dantsis T, Douma C, Giourga C, Loumou A, Polychronaki E (2010) A methodological approach to assess and compare the sustainability level of agricultural plant production systems. Ecol Indic 10:256263. doi:10.1016/j.ecolind.2009.05.007

Darnhofer I, Fairweather J, Moller H (2010) Assessing a farm's sustainability: insights from resilience thinking. Int J Agric Sustain 8:186-198. doi:10.3763/ijas.2010.0480

Devillers J, Farret R, Girardin P, Rivière JL, Soulas G (2005) Indicateurs pour évaluer les risques liés à l'utilisation des pesticides. TEC \& DOC, Lavoisier

Fernandes L, Woodhouse P (2008) Family farm sustainability in southern Brazil: an application of agri-environmental indicators. Ecol Econ 66:243-257. doi:10.1016/j.ecolecon.2008.01.027 
Galan MB, Peschard D, Boizard H (2007) ISO 14001 at the farm level: analysis of five methods for evaluating the environmental impact of agricultural practices. J Environ Manage 82:341-352. doi:10.1016/j.jenvman.2006.06.025

Geniaux G, Bellon S, Deverre C, Powell B (2006) System for Environmental and Agricultural Modelling; Linking European Science and Society. Sustainable Development Indicator Frameworks and Initiatives. http://ageconsearch.umn.edu/bitstream/57937/2/Report 49_PD2.2.1.pdf. Accessed 25 Mar 2011

Gómez-Limón JA, Sanchez-Fernandez G (2010) Empirical evaluation of agricultural sustainability using composite indicators. Ecol Econ 69:1062-1075. doi:10.1016/j.ecolecon.2009.11.027

Gras R (1989) Le Fait technique en agronomie: activité agricole, concepts et méthodes d'étude. Editions L'Harmattan, Paris

Guillaumin A, Hopquin JP, Desvignes P, Vinatier JM (2007) Caractériser la participation des exploitations agricoles d'un territoire au développement durable. Dictionnaire des indicateurs. Institut de l'Elevage, Paris

Halberg N, van der Werf HMG, Basset-Mens C, Dalgaard R, de Boer I (2005a) Environmental assessment tools for the evaluation and improvement of European livestock production systems. Livest Prod Sci 96:33-50. doi:10.1016/j.livprodsci.2005.05.013

Halberg N, Verschuur G, Goodlass G (2005b) Farm level environmental indicators; are they useful?: An overview of green accounting systems for European farms. Agr EcosystEnviron 105:195-212. doi:10.1016/j.agee.2004.04.003

Hostiou N, Dedieu B (2012) A method for assessing work productivity and flexibility in livestock farms. Animal 6:852862. doi:10.1017/S1751731111002084

Lyytimäki J, Rosenström U (2008) Skeletons out of the closet: effectiveness of conceptual frameworks for communicating sustainable development indicators. Sustain Dev 16:301-313. doi:10.1002/sd.330

Meul M, Nevens F, Reheul D, Hofman G (2007) Energy use efficiency of specialised dairy, arable and pig farms in Flanders. Agr Ecosyst Environ 119:135-144. doi:10.1016/j.agee.2006.07.002

Meul M, Van Passel S, Nevens F, Dessein J, Rogge E, Mulier A, Van Hauwermeiren A (2008) MOTIFS: a monitoring tool for integrated farm sustainability. Agron Sustain Dev 28:321-332. doi:10.1016/ j.ecolind.2008.05.007

Meul M, Nevens F, Reheul D (2009) Validating sustainability indicators: focus on ecological aspects of Flemish dairy farms. Ecol Indic 9:284-295. doi:10.1016/j.ecolind.2008.05.007

Nevens F, Verbruggen I, Reheul D, Hofman G (2006) Farm gate nitrogen surpluses and nitrogen use efficiency of specialized dairy farms in Flanders: evolution and future goals. Agr Syst 88:142155. doi:10.1016/j.agsy.2005.03.005

Niemeijer D, de Groot R (2008) A conceptual framework for selecting environmental indicator sets. Ecol Indic 8:14-25. doi:10.1016/ j.ecolind.2006.11.012

Payraudeau S, van der Werf HMG (2005) Environmental impact assessment for a farming region: a review of methods. Agr Ecosyst Environ 107:1-19. doi:10.1016/j.agee.2004.12.012

Ramos TB, Caeiro S (2010) Meta-performance evaluation of sustainability indicators. Ecol Indic 10:157-166. doi:10.1016/ j.ecolind.2009.04.008

Rigby D, Woodhouse P, Young T, Burton M (2001) Constructing a farm level indicator of sustainable agricultural practice. Ecol Econ 39:463-478. doi:10.1016/S0921-8009(01)00245-2

Riley J (2001a) The indicator explosion: local needs and international challenges. Agr Ecosyst Environ 87:119-120. doi:10.1016/ S0167-8809(01)00271-7

Riley J (2001b) Multidisciplinary indicators of impact and change. Key issues for identification and summary. Agr Ecosyst Environ 87:245-259. doi:10.1016/S0167-8809(01)00282-1

Sadok W, Angevin F, Bergez JE, Bockstaller C, Colomb B, Guichard L, Reau R, Doré T (2008) Ex ante assessment of the sustainability of alternative cropping systems: implications for using multicriteria decision-aid methods. A review. Agron Sustain Dev 28:163-174. doi:10.1051/agro:2007043

Sadok W, Angevin F, Bergez JE, Bockstaller C, Colomb B, Guichard L, Reau R, Messéan A, Doré T (2009) MASC, a qualitative multi-attribute decision model for ex ante assessment of the sustainability of cropping systems. Agron Sustain Dev 29:447-461. doi:10.1051/agro/2009006

Sauvenier X, Bielders C, Hermy M, Mathijs E, Muys B, Vanclosster M, Peeters A, Valckx J, Van Cauwenbergh N, Wauters E, Bachev H, Biala K, Brouckaert V, Garcia Cidad V, Goyens S (2005) Framework for assessing sustainability levels in Belgian agricultural systems (SAFE). Part 1 Sustainable production and consumption patterns. Belgian Science Policy, Brussels

Schröder JJ, Aart HFM, Ten Berge HFM, Van Keulen H, Neeteson JJ (2003) An evaluation of whole-farm nitrogen balances and related indices for efficient nitrogen use. Eur J Agron 20:33-44. doi:10.1016/S1161-0301(03)00070-4

Singh RK, Murty HR, Gupta SK, Dikshit AK (2009) An overview of sustainability assessment methodologies. Ecol Indic 9:189-212. doi:10.1016/j.ecolind.2008.05.011

Solagro (2006) Manuel Dialecte. http://dialecte.solagro.org. Accessed 11 Mar 2011

ten Napel J, van der Veen AA, Oosting SJ, Koerkamp PWG (2011) A conceptual approach to design livestock production systems for robustness to enhance sustainability. Livest Sci 139:150-160. doi:10.1016/j.livsci.2011.03.007

Thomassen MA, de Boer IJM (2005) Evaluation of indicators to assess the environmental impact of dairy production systems. Agr Ecosyst Environ 111:185-199. doi:10.1016/j.agee.2005.06.013

Thomassen MA, van Calker KJ, Smits MCJ, Iepema GL, de Boer IJM (2008) Life cycle assessment of conventional and organic milk production in the Netherlands. Agr Syst 96:95-107. doi:10.1016/ j.agsy.2007.06.001

van Calker KJ (2005) Sustainability of Dutch dairy farming systems: a modelling approach. Dissertation, Wageningen Universiteit, Wageningen

van Calker KJ, Berentsen PBM, Romero C, Giesen GWJ, Huirne RBM (2006) Development and application of a multi-attribute sustainability function for Dutch dairy farming systems. Ecol Econ 57:640-658. doi:10.1016/j.ecolecon.2005.05.016

van Calker KJ, Berentsen PBM, de Boer IJM, Giesen GWJ, Huirne RBM (2007) Modelling worker physical health and societal sustainability at farm level: an application to conventional and organic dairy farming. Agr Syst 94:205-219. doi:10.1016/j.agsy.2006.08.006

Van Cauwenbergh N, Biala K, Bielders C, Brouckaert V, Franchois L, Garcia Cidad V, Hermy M, Mathijs E, Muys B, Reijnders J, Sauvenier X, Valckx J, Vanclooster M, Van der Veken B, Wauters E, Peeters A (2007) SAFE - a hierarchical framework for assessing the sustainability of agricultural systems. Agr Ecosyst Environ 120:229-242. doi:10.1016/j.agee.2006.09.006

van der Werf HMG, Petit J (2002) Evaluation of the environmental impact of agriculture at the farm level: a comparison and analysis of 12 indicator-based methods. Agr Ecosyst Environ 93:131-145. doi:10.1016/S0167-8809(01)00354-1

van der Werf HMG, Tzilivakis J, Lewis K, Basset-Mens C (2007) Environmental impacts of farm scenarios according to five assessment methods. Agr Ecosyst Environ 118:327-338. doi:10.1016/j.agee.2006.06.005

van der Werf HMG, Kanyarushoki C, Corson MS (2009) An operational method for the evaluation of resource use and environmental impacts of dairy farms by life cycle assessment. J Environ Manage 90:3643-3652. doi:10.1016/j.jenvman.2009.07.003

van der Werf HMG, Kanyarushoki C, Corson MS (2011) L'Analyse de Cycle de vie: un nouveau regard sur les systèmes de production agricole. Innovations Agronomiques 12:121-133

Vilain L (2008) La méthode IDEA: indicateurs de durabilité des exploitations agricoles. Educagri Editions, Dijon 